\title{
Oxidation of $N$-Methylanilines by a Nonheme Iron(IV)-Oxo Complex
}

\author{
Kasi Nehru, Yu Kyeong Jang, Mi Sook Seo, Wonwoo Nam," and Jinheung Kim* \\ Department of Chemistrv. Division of Nano Sciences, Ewha IV Omans Chiversity, Seoul 120-750. Korea \\ "E-mail: jinheung àewhac.kn; wnamià ewhac. $\mathrm{kr}$ \\ Received January 12. 2007
}

Key Words : Iron-oxo species, Nonheme. Oxidation, $N$-Methylaniline. Electron transfer

High-valent iron-oxo species have been frequently employed in heme and nonheme iron enzymes to carry out catalytic oxygenation reactions. ${ }^{1-11}$ In heme-based systems. biological and syrnthetic oxoiron(IV) porphyrin $\pi$-cation radicals are believed to carry out the catalytic oxidations of organic substrates. In the nonheme iron enzymes oxoiron(IV) intermediates have recently been identified by spectroscopic methods in the catalytic cycle of taurine dioxygenase. and synthetic nonheme oxoiron(IV) species bearing tetradentate and pentadentate ligands were also isolated and characterized. ${ }^{1:-18}$ In addition. it has been demonstrated that the nonheme oxoiron(IV) species were capable of conducting the conversion of diverse organic subsatrates such as $\mathrm{PPh}_{\hat{j}}$. thioanisole. alcohol, and alkanes. ${ }^{18-20}$

The molecular mechanisms of oxidative $N$-demethylation of $N, N$-dimethỵlanilines by heme enzymes such as peroxidases and cytochrome P-450 have been studied for the past twenty years. However. two possible mechanisms. electron transfer followed by proton transfer and hydrogen transfer from $\alpha-\mathrm{C}-\mathrm{H}$ bonds of the methyl group in $N, N$ dimethylanilines, are still under debate. Recently. we also reported the oxidative $N$-dealkylation of $N, N$-dialkylanilines and demonstrated that the oxidative $N$-dealky lation reactions occurred wia a proton-coupled electron transfer process. ${ }^{21}$ Meanwhile. secondary amine substrates bearing a cyclopropyl group have been used in the relation to a mechanismbased inactivation of heme enzymes. and the formation of a highly reactive carbon-centered radical was reported in the oxidation of heteroatom-containing cyclopropyl substrates. ${ }^{2-27}$ Relatively, a few studies for the oxidation of $N$ methỵlanilines as substrate were reported using iron cobalt. and copper complexes. ${ }^{-\delta-30}$ However no detailed mechanistic study in the oxidation of secondary amines with nonheme $\mathrm{Fe}$ (IV)-oxo species has been reported until now. Presented in this study is a kinetic examination of the oxidation of $N$-methylanilines with $\left[(\operatorname{tmc}) \mathrm{Fe}^{\mathrm{IV}}=\mathrm{O}\right]^{2+}(\operatorname{tmc}=$ 1.4.8.11-tetramethy 1-1.4.8.11-tetraazacyclotetradecane).

which yields $N, N^{\prime}$-dimethyl- $N, N^{\prime}$-dipheny lhỵdrazine formed by the coupling of two $N$-methylaniline molecules. By determining the rate constants for the step of electron transfer from $N$-methylaniline to the iron(IV)-oxo species. we suggest that the oxidation of $N$-methylaniline occurs via an electron transfer.

\section{Experimental Procedure}

Materials and Instrumentation. All chemicals obtained from Aldrich Chemical Co. were the best available purity and used without further purification unless otherwise indicated. Solvents were dried according to published procedures and distilled under Ar prior to use. Fe(tmc)(OTf): $2 \mathrm{CH}_{3} \mathrm{CN}$ was prepared in a glovebox by literature methods. para-Methyl- $N$-trideuteromethylaniline- $d_{3}\left(\mathrm{Me}-\mathrm{MA}-d_{5}\right)$ was prepared by literature methods. ${ }^{31}$

UV-vis spectra were recorded on a Hewlett Packard 8453 spectrophotometer equipped with Optostat ${ }^{\mathrm{DN}}$ variabletemperature liquid-nitrogen cryostat (Oxford Instruments) or with a circulating water bath. LC-MS spectra were collected on Surveyor Integrated HPLC systems connected with Thermo Finnigan (San Jose. CA. USA) LCQ ${ }^{\mathrm{TM}}$ Advantage MAX quadrupole ion trap instrument. Product analysis for the oxidation of $N$-methylanilines was performed either on DIONEX Pump Series P 580 equipped with a variable wavelength UV-200 detector (HPLC) or on Agilent Technologies $6890 \mathrm{~N}$ gas chromatograph (GC) and a HewlettPackard 5890 II Plus gas chromatograph interfaced with Hewlett-Packard model 5989B mass spectrometer (GCMS). Product analy sis for the oxidation of $N$-methylanilines was performed on GC and LC-MS

Reactions of the Oxoiron(IV) Complex with $p$-Substituted- $N$-methylaniline. In general, reactions were nun at least in triplicate, and the data represent average of these reactions. All reactions were followed by monitoring spectral changes of reaction solutions with a UV-vis spectrophotometer. The nonheme oxoiron(IV) complex was prepared by adding 1.2 equiv of $\mathrm{PhIO}(2.4 \mathrm{mM}$. diluted in 50 $\mu \mathrm{L}$ of $\left.\mathrm{CH}_{3} \mathrm{OH}\right)$ into an $1-\mathrm{cm}$ UV cuvette containing an iron(II) complex (2 mM). Fe(TMC)(OTf) 2 in $\mathrm{CH}_{3} \mathrm{CN}(2$ $\mathrm{mLL}$ ). Then, appropriate amounts of $N$-methylanilines were added into the UV cuvette. and spectral changes of the oxoiron(IV) complex were directly monitored by a UV-vis spectrophotometer. Rate constants. $k_{\text {cts. }}$ were determined by pseudo-first-order fitting of the decrease of absorption bands at $820 \mathrm{~nm}$.

Product Analysis for the Oxidation of $N$-Methylanilines. A reaction solution containing the oxoiron(IV) intermediate $(2 \mathrm{mM})$ was prepared as described above. Then. 20 equiv of 
$N$-methylaniline $(40 \mathrm{mM})$ was added to the reaction solution. Product analysis was performed by injecting reaction solutions directly into LC-MS. GC. and/or GC-MS. Product yields were determined by comparison with standard curves of known authentic samples.

ln kinetic isotope effect study by kinetics. Me-MA/MeMA- $d_{3}(40 \mathrm{mM})$ was treated to reaction solutions containing the oxoiron(IV) intermediate $(2 \mathrm{mM})$.

\section{Results and Discussion}

The mononuclear nonheme oxoiron(IV) complex. [(tmc)$\left.\mathrm{Fe}^{1 \mathrm{r}}=\mathrm{O}\right]^{2+}$, is prepared in the reaction of their corresponding Fe(II) complex, [(tmc) $\left.\mathrm{Fe}(\mathrm{OTf})_{2}\right]^{3+}$, by using the method reported previously. ${ }^{16,21}$ In the reaction with 20 equiv paramethyl- $N$-methylaniline ( $p$-Me-MA), the oxoiron(IV) species reverted back to the starting iron(II) complex at room temp. showing pseudo-first-order decay as monitored by a UV-vis spectrophotometer (Figure la). The observed psendo-firstorder rate constants for $\mathrm{Fe}(\mathrm{IV})=\mathrm{O}$ decomposition increased linearly with $p$-Me-MA concentration, leading us to determine second-order rate constant $(k)$ of $1.10 \pm 0.05 \mathrm{M}^{-1} \mathrm{~s}^{-1}$ (Figure Ib). This rate constant is slightly low compared to that observed in the oxidation of para-Me-N,N-dimethylaniline by the same catalyst $\left(k_{2}=1.2 \pm 0.1 \mathrm{M}^{-1} \mathrm{~s}^{-1}\right){ }^{21}$ We then determined activation parameters of $\Delta H^{\downarrow}$ and $\Delta S^{\dagger}$ for the oxidation of $p$-Me-MA by $\left[(\mathrm{tmc}) \mathrm{Fe}^{\mathrm{IV}}=\mathrm{O}\right]^{2-}$, by determining rate constants at different temperatures $\left(\Delta H^{+}=54 \mathrm{~kJ}\right.$ $\mathrm{mol}^{-1}$ and $\Delta S^{+}=-81 \mathrm{JK}^{-1} \mathrm{~mol}^{-1}$. Figure lc).

The product analysis of the resulting solutions with HPLC revealed that no $N$-demethylated product was detected and the coupling product of $N, N^{\prime}$-dimethyl- $N, N^{\prime}$-diphenylhydrazine was generated $\left(30 \%\right.$, based on $\left[(\mathrm{tmc}) \mathrm{Fe}^{\mathrm{IV}}=\mathrm{O}\right]^{\hat{2}^{-}}$) (Figure 2). In the oxidation of $\mathrm{N}$-methylanilines with a synthetic $\mathrm{Fe}^{\mathrm{IV}}=\mathrm{O}$ porphyrin $\pi$-cation radical or $\mathrm{CuCl} / \mathrm{O}_{3}$, the formation



of such coupling products was also reported ${ }^{3 y, 3 i j}$ But other possible coupling products such as benzidine and diphenylamine were not observed. which were predominant pathways for the electrochemical anodic oxidation of $N$-methyl-

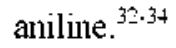

The effects of ring substituents in para-substituted- $N$ methylanilines ( $p$-X-MAs) were also investigated on the


Figure 1. Reactions of $\left[(\right.$ tme $) \mathrm{Fe}^{1 \mathrm{v}}=\mathrm{O}^{2+}$ with $\mathrm{N}$-methylanilines in $\mathrm{CH}_{3} \mathrm{CN}$ at $25^{\circ} \mathrm{C}$. (a) Time-resolved UV-vis spectral changes upon addition of 20 equiv of $p$-Me-MA. Inset shows absorbance traces monitored at $820 \mathrm{~mm}$. (b) Plot of the observed pseudo-first-order rate constant at variable $p$-Me-MA concentrations. (c) Deteminition of activation parameters by plotting first-order-rate constants determined upon addition of 20 equiv of $p$-Me-MA at different temperatures against $1 / T$.

(a)



(b)

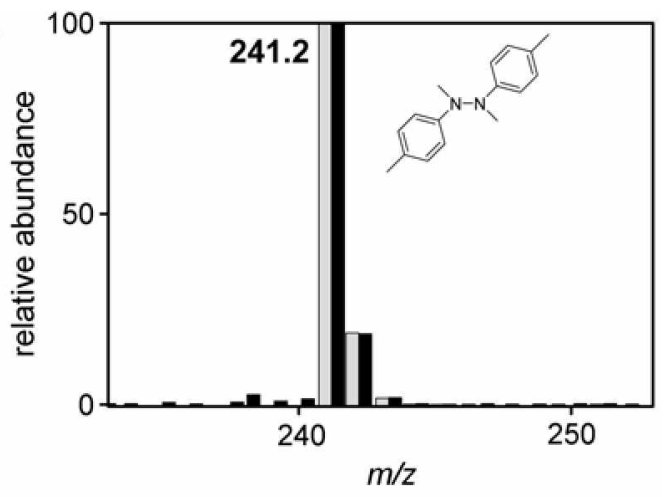

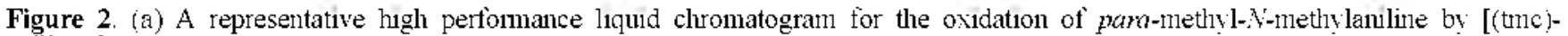

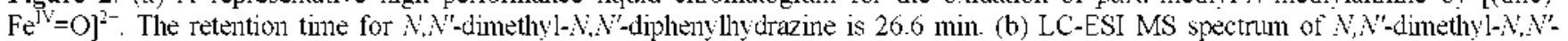
diphenyllydrazme. 




Figure 3. Correlation of the Hammett substituent constant $\left(\sigma_{p}\right)$ and the pseudo-first-order rate constants in the presence of excess $p$-XMA.

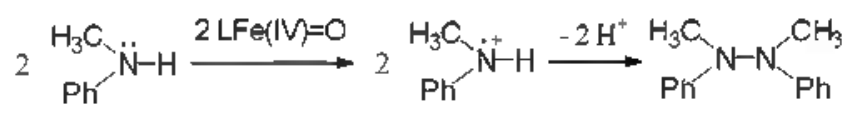

Scheme 1

rates of decomposition of $\left[(\mathrm{tmc}) \mathrm{Fe}^{\mathrm{IV}}=\mathrm{O}\right]^{2+}$. As shown in Figure 3. the decay rates for the $\mathrm{Fe}($ IV) $=\mathrm{O}$ species correlate with Hammett $\sigma_{\mathrm{p}}$ values to give large negative $\rho$ values $(-1.96)$ for $\left[(\mathrm{tmc}) \mathrm{Fe}^{\mathrm{IV}}=\mathrm{O}\right]^{++}$. Hence, increasing the donating ability of $p$-X-MAs dininishes the stability of the $\mathrm{Fe}(\mathrm{IV})=\mathrm{O}$ species. as previously observed for the alcohol and N.Ndimethylaniline oxidation by $\left[(\mathrm{tmic}) \mathrm{Fe}^{\mathrm{IV}}=\mathrm{O}\right]^{2-}$. ${ }^{2, \imath l}$ This strongly suggests that the para-substituents affect the positivelycharged transient state intermediate of $\left[\left(\mathrm{tmic}_{\mathrm{c}}\right) \mathrm{Fe}^{\mathrm{IV}}=\mathrm{O}\right]^{\hat{i}^{-}} \mathrm{by}$ the inductive effect during the first event of oxidation of MAs. It should be noted that such large negative values were observed by the kinetic analysis in the oxidation of parcsubstituted- $N, N$-dimetlylanilines with $\mathrm{Cu}^{\mathrm{II}}-\mu$-peroxo species ${ }^{3-5}$ and in the oxidation of para-substituted-anilines by (salen)$\mathrm{Cr}=\mathrm{O},{ }^{30}$ in which the rate-liniting electron transfer process was also proposed.

The additional hint for the reaction mechanism of $N$ methylaniline oxidation by $\left[(\text { tmc }) \mathrm{Fe}^{\mathrm{IV}}=\mathrm{O}\right]^{2+}$ was obtained from kinetic study in the experiments with a deuteriumlabeled substrate. Kinetic isotope effects (KIE) obtained following the decay of the absorption bands of $\left[(\mathrm{tmc}) \mathrm{Fe}^{\mathrm{IV}}\right.$ $=\mathrm{O}^{2+}$ with $p a r a-$ methyl- $N$-methylaniline and pora-methyl$N$-trideuteromethylaniline turned out 1.1 , which strongly supports that only the electron transfer reaction from MA to the oxoiron(IV) intermediates is involved in the primary rate-determining step and the rate-determining electron transfer step not coupled with the following proton transfer.

The oxidation of $N$-methylanilines by the $\mathrm{Fe}(\mathrm{IV})=\mathrm{O}$ species used in this study may proceed by one-electron oxidation at the nitrogen atom (Scheme 1) to generate an anilinium radical ion. The anilinium ion then combine with another ion to form a stable dimer of hỵdrazine after losing two protons.

\section{Conclusion}

We have carried out the reaction of a nonheme $\mathrm{Fe}{ }^{\mathrm{IV}}=\mathrm{O}$ species with $N$-metlylanilines by the spectral. kinetic, and product analysis studies. These experimental results show that the nonheme $\mathrm{Fe}^{\mathrm{IV}}=\mathrm{O}$ species achieves $N$-methylaniline oxidation through the rate-determining electron transfer.

Acknowledgments. This work was supported by a grant from Center for Applied Superconductivity Teclunology of the 2lth Century Frontier R\&D Program funded by the Ministry of Science and Technology (2006 to J.K.), the SRC/ERC program of MOST/KOSEF (Rll-2005-008$00000-0$ to J.K.), and KOSEF/MOST through Creative Research Initiative Program (to W.N.).

\section{References}

1. Meunier. B: Visser. S. P. d.: Shaik, S. Chem. Rem 2004. 104. 3947.

2. Naml. W: Ryul. Y. O.: Song. W. T. J. Biol. Horg. Chent 2004. 9. 654

3. Shaik, S.: de Visser. S. P.: Kumar. D. J. Biol. Inorg. Chem. 2004. 9. 661 .

4. Groves. J. T. Proc. Fatl Acad Sci. LS 4 2003. 100, 3569.

5. Sono. M.: Roach. M. P.: Coulter. E. D.: Dawsonl. T. H. Chem. Re' 1996. 96. 2841 .

6. Borovik. A. S. Acc. Chem, Res. 2005. 38. 54.

7. Costas, M.: Mehn, M. P.: Jensen. M. P: Que. L. Jr. Chem. Rev 2004. $10+939$.

8. He. C. Mishina. Y. Cwo Opin. Chem. Biol. 2004. 8. 201.

9. Slep. L. D.: Neese. F. Angew. Chem. Int. Ed. 2003. 12.2942

10. Solomon. E. 1.: Brunold. T. C.: Daqis. M. 1.: Kemsley. T. N.: Lee. S.-K.: Lehnert. N.: Neese. F.: Skulan. A. T.: Yang. Y.S.: Zhou. T Chen Rev 2000. 100. 235.

11. Denisov, I. G.; Makris. T. M.: Slıgar. S. G.: Schlıchting. 1. Chem. Rev $2005,105.2253$.

12. Price. J. C.: Barr. E. W: Tirupati. B.: Bollinger. T. M. Tr:: Krebs. C Biochentistry 2003. 12.7497

13. Price. J. C.: Barr. E. W: Glass. T. E.: Krebs. C.: Bollinger. J. M. Jr. J. Am. Chem. Soc. 2003. 125, 13008.

14. Proshlyatov, D. A: Henshaw; T. F.: Monterosso. G. R.: Ryle. M. J.: Hausinger, R. P. J. Am. Chem. Soc. 2004. 126, 1022.

15. Riggs-Gelasco. P. J.: Price. J. C.: Guyer. R. B.: Brehmn. J. H.: Barr. E. W.: Bollinger. J. M. Tr:. Krebs. C.J. Ant Chem. Soc. 2004. 126. 8108.

16. Rohde, J.-U.: In. J.H.: Lim. M. H.; Brennessel. W. W.; Bukowski. M. R: Stubna, A: Munck. E: Nam, W: Que, L. Jr. Science 2003. 299. 1037 .

17. Lim. M. H.: Rohde. J.-U.: Stubna. A.: Bukowski. M. R.: Costas. M.: Ho. R. Y. N.: Munck. E.: Nam. W.: Que. L. Ir. Proc. Matl. Acad. Sci. LSA 2003. 100.3665.

18. Kaizer. J.; Klnker, E. J: Oh. N. Y.: Rohde, J.-L : Song. W. J.; Stubna, A: Kım, J: Munck. E.: Nam. W: Que, L. Jr, J. An. Chem. Soc. $2004,126.472$.

19. Oh. N. Y: Suh. Y.: Park. M. J.: Seo. M. S.: Kimn. T.: Nam. W Angew. Chem. Int Ed 2005. H. 4235.

20. You. M.: Seo. M. S.: Nam. W.: Kiml. J. Bull Korean Chent. Soc. 2006. 27,1140 .

21. Nehru, K.: Seo, M. S.; Kim. J.: Nam, W. homg. Chem. 2007, 46. 293.

22. Guengerich. F. P.: Willard. R. T.: Shea. J. P.: Richards. L. E.: Macdonald. I. L. J. Am. Chen. Soc. 1984. J06. 6446.

23. Newcomb. M.: Toy. P. H. Acc. Chent Res 200. 33.449.

24. Zhao. G.: Qu, J.: Davis, F. A.; Jorns. S. Biochemisty 2000. 39. 14341

25. Hanzlik, R. P.: Tullman, R. H. J. Am. Chem. Soc. 1982, 104. 2048

26. Guengerich. F. P.: Macdonald. T. L. Acc. Chent. Res. 1984. 17.9. 
27. Macdonald. T. L.: Zirvi. K.: Burka. L. T.: Peyman. P.: Guengerich. F. P. J. Am. Chem. Soc. 1982. 104. 2050

28. Sobkowiak. A.: Sawyer. D. T. J. Ant Chem. Soc. 1991. 113.9520.

29. Dicken. C. M.: Lu. F.-L.: Nee. M. W. Bruice. T. C. J. Am. Chem. Soc. $1985,107.5776$.

30. Kajimoto. T:; Takahashi. H.; Tsuji. I. Bull. Chem. Soc. Jpn. 1982. 55.3673 .

31. Dinnecenzo. J. P.: Karki. S. B.: Jones. J. P. J. Am. Chem. Soc. 1993. 115.7111 .
32. Galus. Z.: Adams. R. N. J. Phys Chent 1963.67.862

33. Berti. C.: Greci. L.: Andruzzi. R.: Trazza. A. J. Org. Chent 1985. 50.368 .

34. Hand. R. L.: Nelson. R. F. J. Am. Chem. Soc. 1974. 96,850 .

35. Shearer, J: Zhang, C. X.: Hatcher. L. Q: Karlin. K. D. J. Am Chem. Soc. 2003, 125. 12670.

36. Premsingh. S.: Venkataramanan. S. N.: Rajagopal. S.: Miza. S. P.: Vairamani. M.: Rao. P. S.: Velavan. K. Inorg Chent 2004. +3. 5744 